\title{
ODGOVORNOST ČLANOVA ORGANA DRUŠTAVA U FAKTIČNOM KONCERNU
}

Dr. sc. Antun Bilić*

Prof. dr. sc. Siniša Petrović**

\author{
UDK 347.72.036:347.56 \\ https://doi.org/10.30925/zpfsr.39.2.1 \\ Ur.: 3. svibnja 2018. \\ Pr.: 24. svibnja 2018. \\ Izvorni znanstveni rad
}

\begin{abstract}
Sažetak
U radu se razmatraju najvažnija pitanja odgovornosti članova organa društava koja se nalaze u sastavu faktičnog koncerna. Odgovornost članova organa društava u faktičnom koncernu ultimativno ovisi o opsegu njihovih ovlasti. Da bi se utvrdile te ovlasti prvo se razmatra pojam faktičnog koncerna u kontekstu prava povezanih društava, a potom i učinci koncernskog prava na odnos između vladajućeg i ovisnog društva. Dolazi se do zaključka da, iako to ne bi smjelo, vladajuće društvo redovito može navesti ovisno društvo na određeno postupanje. Zbog toga je prvenstvena svrha pravila o granicama utjecaja vladajućeg društva zaštititi manjinske članove $i$ vjerovnike ovisnoga društva zabranom davanja uputa koje su štetne po ovisno društvo. Vladajuće društvo ovlašteno je davati štetne upute ovisnome društvu, samo iznimno, kada mu ih nadoknadi ili se obveže nadoknaditi do kraja poslovne godine. Takav privilegij vladajućeg društva je uravnotežen pravilima o objektivnoj odgovornosti vladajućeg društva za štetu te pravilima o odgovornosti za štetu njegovih zakonskih zastupnika na temelju pretpostavljene krivnje. Za učinkovitu zaštitu ovisnoga društva ključna je uloga njegove uprave koja je dužna pozornošću urednog i savjesnog gospodarstvenika procijeniti jesu li upute štetne po ovisno društvo te, ako jesu, je li ih vladajuće društvo spremno i u mogućnosti nadoknaditi.
\end{abstract}

Ključne riječi: faktični koncern, vladajuće i ovisno društvo, granice utjecaja vladajućeg društva, odgovornost članova organa, uprava.

\section{UVOD}

Iako egzaktni podaci nisu dostupni, za pretpostaviti je da se veliki broj hrvatskih društava kapitala nalazi u sastavu faktičnog koncerna između vladajućeg i ovisnog društva. Za postojanje takvog koncerna je, naime, najčešće, dovoljno da jedno društvo

* Dr. sc. Antun Bilić, poslijedoktorand Pravnog fakulteta Sveučilišta u Zagrebu; antun.bilic@ pravo.hr.

** Dr. sc. Siniša Petrović, redoviti profesor u trajnom zvanju Pravnog fakulteta Sveučilišta u Zagrebu; sinisa.petrovic@pravo.hr. 
u drugome ima većinu udjela u temeljnom kapitalu, odnosno većinu glasova u skupštini društva (čl. 474-476 Zakona o trgovačkim društvima, dalje: ZTD ${ }^{1}$ ). Osim velikih koncerna dioničkih društava koji su od značaja za čitavo nacionalno gospodarstvo, u praksi se mogu susresti i mnogi „mali“ koncerni više društava s ograničenom odgovornošću, možda čak i jednostavnih društava s ograničenom odgovornošću. Ako se tome pribroje i društva kapitala koja se nalaze u odnosu ovisnosti u odnosu na člana fizičku osobu, odnos ovisnosti jedno je od najčešćih stanja u kojem se može nalaziti društvo kapitala.

Za faktični koncern vladajućeg i ovisnog društva svojstveno je da je vladajuće društvo steklo prevladavajući utjecaj u odnosu na drugo društvo (čl. 475 st. 1 ZTD). Potrebno je odgovoriti na pitanje kako ta okolnost utječe na opća pravila prava društava? Treba li prevladavajući položaj, najčešće stečen ulaganjem kapitala, posebno honorirati, dajući vladajućem društvu privilegije koji ne bi proizlazili iz njegovog članskog statusa ili ga pak dodatno opteretiti, namećući vladajućem društvu obveze radi zaštite manjinskih članova i vjerovnika ovisnoga društva?

Ta se pitanja izravno prelijevaju na ulogu organa društava u faktičnom koncernu, u prvom redu upravu ovisnoga i vladajućeg društva. Ravnaju li se uprave ovisnog i vladajućeg društva prema općim pravilima korporativnog upravljanja, koja bi zahtijevala da one djeluju načelno nezavisno jedna od druge (čl. 240 st. 1, 252, 430 ZTD) ili se upravi vladajućeg društva daju posebne ovlasti utjecati na upravu ovisnoga društva? Odgovor na to pitanje bi se pak trebao izravno odražavati na odgovornost članova uprave. Ukratko rečeno, što su ovlasti uprave vladajućeg društva u odnosu na ovisno društvo veće, veća bi trebala biti i odgovornost njezinih članova za štetu nastalu ovisnome društvu. Jednako tako, ako je uprava ovisnoga društva samostalna u svojem djelovanju, odgovornost njezinih članova ne bi se trebala razlikovati od općih pravila o odgovornosti članova uprave.

$\mathrm{S}$ obzirom na važnost problema, u dosadašnjoj hrvatskoj pravnoj znanosti relativno je malo radova posvećeno faktičnom koncernu, a još manje radova bavi se ulogom i odgovornošću organa društava u sastavu faktičnog koncerna. ${ }^{2} U$ sudskoj

$1 \quad \mathrm{NN}$ br. $111 / 93,34 / 99,121 / 99,52 / 00,118 / 03,107 / 07,146 / 08,137 / 09,125 / 11,111 / 12,68 / 13 \mathrm{i}$ $110 / 15$.

2 Faktični koncern detaljnije je razmatran u Barbić, J., Pravo društava, Knjiga prva, Opći dio, Zagreb, Organizator, 2008, str. 633-673; Barbić, J., Koncern i društva koncerna, Pravo u gospodarstvu, vol. 46, 4/2007, str. 57-94; Barbić, J., Vođenje poslova i upravljanje u trgovačkim društvima (povezana društva), Hrvatska gospodarska revija, vol. 45, 11/1996, str. 1574-1582; Ceronja, P., O odgovornosti članova nadzornog odbora ovisnog društva za štetu zbog povrede obveze nadzora tražbina iz ugovora o zajmu sklopljenih između ovisnog i vladajućeg društva, Pravo u gospodarstvu, vol. 50, 5/2011, str. 1158-1176; Cindori, V., Izvješće o ovisnosti trgovačkih društava s aspekta poslovanja društava, Informator, 5436/2006, str. 6-8; Jurić, D., Odgovornost vladajućeg društva za obveze ovisnog društva u hrvatskom i usporednom pravu, Zbornik Pravnog fakulteta Sveučilišta u Rijeci, vol. 23, 2/2002, str. 507-540; Jurić, D., Transparentnost statusnih i financijskih odnosa povezanih društava, Zbornik Pravnog fakulteta Sveučilišta u Rijeci, vol. 27, 2/2006, str. 939-984; Braut Filipović, M., Odgovornost društva majke za obveze društva kćeri, Zbornik Pravnog fakulteta Sveučilišta u Rijeci, vol. 32, 2/2011, str. 795-828; Gorenc, V., Povezana društva prema Zakonu o trgovačkim društvima, Računovodstvo, revizija i financije, vol. 4, 10/1994, str. 1786-1797; Ledić, D., Povezana društva - začetak hrvatskog 
praksi koja je bila dostupna za potrebe ovoga istraživanja, ${ }^{3}$ pojam koncerna općenito se vrlo rijetko koristi. Izgleda da sudovi radije govore o povezanim društvima, ne upuštajući se u kvalifikaciju dovodi li određeni oblik povezanosti do nastanka koncerna. Pronađene su samo dvije presude koje uopće spominju pojam faktičnog koncerna. $^{4}$

Cilj je ovoga rada pružiti osnovni teoretski okvir za razmišljanje o odgovornosti članova organa društava u faktičnom koncernu. Da bi se to postiglo rad će se svjesno ograničiti na temelje odgovornosti te će izostaviti određene dijelove zakonskog uređenja faktičnog koncerna, primjerice konsolidirana izvješća o stanju društva (čl. 250.b ZTD), konsolidirana godišnja financijska izvješća (čl. 300.d st. 2 ZTD) te izvješća o odnosima s povezanim društvima (čl. 497-500 ZTD).

Osim davanja teoretskog okvira, cilj je ovog rada pružiti upute za budući razvoj sudske prakse. Budući da su tužbe protiv članova uprava na naknadu štete jedne od najčešćih korporativnih tužbi, ${ }^{5}$ pitanje uloge i odgovornosti uprave društva u faktičnom koncernu je od iznimne praktične važnosti.

Ishodišna točka za proučavanje odgovornosti članova organa u faktičnom koncernu tekst je zakonskih odredbi o faktičnom koncernu. Rad će se osobito fokusirati na odgovornost zakonskih zastupnika vladajućeg društva i članova organa ovisnoga društva kako su predviđene u čl. 501 i 502 ZTD-a. Posebno uređenje odgovornosti članova organa društava u koncernu moglo bi navesti na zaključak da je riječ o odredbama koje iscrpljuju spomenutu materiju i kojima se zamjenjuje opći režim odgovornosti članova organa iz čl. 252 ZTD-a. Cilj je ovog rada detaljnije preispitati tu tezu.

Zakonske odredbe $u$ faktičnom koncernu analizirat će se kako same za sebe tako i u kontekstu ostalih odredbi prava društava. Uzet će se u obzir aktualna pravna teorija i sudska praksa. Njima će se kritički pristupiti i pokušat će se dati preporuke za njihov budući razvoj. U obzir će se uzeti i pravna teorija i praksa njemačkoga prava, s obzirom na to da su hrvatska pravila o koncernu uvelike preuzeta iz njemačkog Zakona o dioničkim društvima. ${ }^{6}$

prava koncerna, Zbornik Pravnog fakulteta Sveučilišta u Rijeci, vol. 16, 1/1995, str. 37-51; Moslavac, B, Pitanje odgovornosti u slučaju ovisnosti društva kada nema ugovora o vođenju poslova društva, Informator, vol. 56, 5695-5696/2008, str. 5-7; Vidović, A., Koncern - aktualna pitanja povezivanja društava, Računovodstvo, revizija i financije, vol.18, 3/2008, str. 194-195.

3 Riječ je o ukupnoj sudskoj praksi koja je objavljena na mrežnim stranicama Vrhovnoga suda i portala IUSinfo.

4 I to u kontekstu kvalificiranog faktičnog koncerna, VSRH Revt 159/11-2 od 24.1.2012. i VTS Pž-1760/02 od 15.4.2003. (sentenca na IUSinfo).

5 V. pregled sudske prakse u: Barbić, J., Pravo društava, Knjiga druga, Društva kapitala, Svezak I., Dioničko društvo, Zagreb, Organizator 2013, str. 834, 846-850, 855-868; Barbić, J., Pravo društava, Knjiga druga, Društva kapitala, Svezak II., Društvo s ograničenom odgovornošću, Zagreb, Organizator, 2013, str. 404-410.

6 § 311-318 Aktiengesetz. Od njemačke literature v. osobito: Emmerich, V., u: Emmerich, V.; Habersack, M.; Schürnbrand, J. (ur.), Aktien- und GmbH-Konzernrecht, München, C. H. Beck, 2016., § 15-18 AktG; Habersack, M. u: Emmerich, V.; Habersack, M.; Schürnbrand, J. (ur.), Aktien- und GmbH-Konzernrecht, München, C. H. Beck, 2016., § 311-318 AktG; Bayer, W. u: Goette, W.; Habersack, M. (ur.), Münchener Kommentar zum Aktienrecht, Band 1, München, 
Za razumijevanje odgovornosti članova organa faktičnog koncerna, nužno je razumjeti faktični koncern i njegovu ulogu u općim pravilima prava društava. Zbog toga će se prvo izložiti što je to faktični koncern i kako se on odnosi prema ostalim pojmovima povezanih društava (2.). Nakon toga će se pristupiti analizi odnosa ovisnog i vladajućeg društva koji determinira odnose i ovlasti njihovih organa (3.). Nakon toga će se razmotriti pravila o odgovornosti članova organa vladajućeg društva (4.) te pravila o odgovornosti članova organa ovisnoga društva (5.). Rad završava zaključkom u kojem će se sažeti najvažniji rezultati istraživanja (6.).

\section{POJAM I PRETPOSTAVKE FAKTIČNOG KONCERNA}

ZTD definira koncern kao više pravno samostalnih društava objedinjenih jedinstvenim, odnosno zajedničkim vođenjem (čl. 476 ZTD). ${ }^{7}$ Pravna samostalnost povezanih društva je učestalo isticana i u sudskoj praksi. ${ }^{8}$ Ona znači da društva koncerna imaju vlastitu imovinu i dugove koji se razlikuju od imovine i dugova drugih društava koncerna. Do odgovornosti za dugove drugoga društva koncerna može doći samo u iznimnim slučajevima kada je položaj u koncernu omogućio vladajućem društvu zloupotrebu okolnosti da kao član trgovačkog društva ne odgovara za obveze društva (čl. 10 st. 3 ZTD). ${ }^{9}$

Konstitutivni element koncerna, jedinstveno vođenje, blizak je pojmu vođenja poslova društva koji se definira kao djelovanje usmjereno na ostvarenje cilja zbog kojega je društvo osnovano. ${ }^{10} \mathrm{Za}$ takvu je definiciju, dakle, ključan cilj kao neodvojivi dio svakog pojedinog društva. ${ }^{11}$ Budući da je vođenje poslova društva usmjereno na ostvarenje njemu svojstvenog cilja, jedinstveno vođenje poslova više različitih društava bi pravnoteorijski predstavljalo kontradikciju. Ciljevi trgovačkih društava se, međutim, u praksi najčešće svode na ostvarenje što je moguće veće dobiti na tržištu. Zbog toga nije neuobičajeno da više samostalnih pravnih društava poveže svoje poslovne aktivnosti radi ukupnog maksimiziranja dobiti. Drugim riječima, kada

C. H. Beck, 2016., § 15-19 AktG; Altmeppen, H. u: Goette, W.; Habersack, M. (ur.), Münchener Kommentar zum Aktienrecht, Band 5, München, C. H. Beck/Franz Vahlen, 2015., § 311-318 AktG; Schall, A. u: Spindler, G.; Stilz, E. (ur.), Kommentar zum Aktienrecht, Band 1, München, C. H. Beck, 2015., § 15-19 AktG; Müller, H-F. u: Spindler, G.; Stilz, E. (ur.), Kommentar zum Aktienrecht, Band 2, München, C. H. Beck, 2015., § 311-318 AktG; Koch, J. u: Hüffer, U.; Koch, J. (ur.), Aktiengesetz, München, C. H. Beck, 2015., § 15-19, § 311-318 AktG; Krieger, G., u: Hoffmann-Becking, M. (ur.), Münchener Handbuch des Gesellschaftsrechts, Band 4, München, C. H. Beck, 2015, § 69-70.

7 Tako i § $18 \mathrm{AktG}$.

8 VSRH Revt 60/04-2 od 6.10.2004.; VSRH Revr 344/08-2 od 17.6.2009.; VSRH Revt 159/11-2 od 24.1.2012.; VTS Pž-1934/06-3 od 22.4.2009.

9 Izgleda ipak da je to jedan od najčešćih povoda kada se u hrvatskoj sudskoj praksi razmatraju povezana društva i koncern (v. VSRH Revt 159/11-2 od 24.1.2012., VSRH Revt 60/04-2 od 6.10.2004.; VTS Pž-1760/02 od 15.4.2003. (sentenca na IUSinfo); VTS Pž 2859/04-3 od 6.11.2007.; VTS Pž 7222/04-3 od 11.10.2005.; VTS Pž 6097/05-3 od 29.5.2007.). V. i Braut Filipović, M., op. cit. u bilj. 2. i Jurić, D., Odgovornost vladajućeg društva, op. cit. u bilj. 2.

10 Barbić, J., Dioničko društvo, op. cit. u bilj. 5, str. 746.

11 O konstitutivnosti cilja za pojam društva v. Barbić, J., Opći dio, op. cit. u bilj. 2, str. 133. 
zakon govori o jedinstvenom vođenju, on pod time misli na poslovno jedinstveno ponašanje na tržištu. Koncernski pojam jedinstvenog vođenja je, dakle, primarno poslovni, gospodarski pojam, koji tek sekundarno dovodi do pravno relevantnih učinaka. ${ }^{12}$ Zbog toga bi se moglo reći da već i opći pojam koncerna podrazumijeva postojanje, tzv. faktičnog koncerna.

Za jedinstveno vođenje traži se da više pravno samostalnih društava na tržištu djeluju kao potpuno gospodarsko jedinstvo (tzv. uži pojam koncerna) ili barem kao gospodarsko jedinstvo neke od temeljnih poduzetničkih djelatnosti, najčešće putem središnjeg organiziranja financija (tzv. širi pojam koncerna) ${ }^{13}$ Zakon predviđa da do jedinstvenog vođenja može doći kako u odnosu vladajućega prema ovisnome društvu (čl. 476 st. 1 ZTD) tako i u odnosu između društava koja nisu ovisna jedno o drugome (čl. 476 st. 2 ZTD). Ovaj će se rad orijentirati isključivo na koncern vladajućeg i ovisnoga društva jer je on češći u praksi ${ }^{14}$ i u zakonu detaljnije uređen (čl. 496-502 ZTD). Neki temeljni zaključci do kojih se dođe u radu bi se, međutim, na odgovarajući način mogli primijeniti i na koncern društava koja nisu u odnosu ovisnosti.

Jedinstveno vođenje zakonom je namjerno široko definirano da bi moglo pokriti različite pojavne oblike zajedničkog nastupanja na tržištu. ${ }^{15}$ To, s druge strane, ostavlja širok prostor pravnoj nesigurnosti. Zbog toga je zakonodavac odlučio olakšati dokazivanje koncerna određenim presumpcijama. Zakon tako postavlja neoborivu presumpciju da se radi o koncernu kada je između društava koncerna sklopljen ugovor o vođenju poslova društva (tzv. ugovorni koncern, čl. 479 ZTD) ili kada je jedno društvo priključeno drugome (koncern priključenjem, čl. 503 ZTD). Za sve ostale oblike koncerna u pravnoj teoriji uvriježio se naziv faktični koncern. ${ }^{16}$ Drugim riječima, faktični koncern odgovara općem pojmu koncerna nakon što se isključe specifični oblici, kod kojih ex lege dolazi do jedinstvenog upravljanja (čl. 493, čl. 507 ZTD).

Zakonodavac je konkretizirao faktični koncern s pomoću oborive presumpcije da vladajuće i ovisno društvo čine koncern (čl. 476 st. 1 ZTD). Vladajuće i ovisno društvo se, međutim, i sami apstraktno definiraju putem posredno ili neposredno prevladavajućeg utjecaja koji vladajuće društvo može imati u ovisnome društvu (čl. 475 st. 1 ZTD). Dokazivanje toga se olakšava sljedećom presumpcijom, prema kojoj je društvo koje ima većinu udjela u temeljnom kapitalu u nekom društvu ili većinu prava glasa u tome društvu vladajuće u odnosu na to društvo (tzv. većinsko sudjelovanje čl. 475 st. 2, čl. 474 ZTD). To je relativno jednostavno dokazati na temelju preciznih zakonskih uputa kako se utvrđuje većina udjela, odnosno broj glasova u skupštini (čl. 474 st. 2-4). Promatrano iz druge perspektive, najjednostavniji oblik povezanosti više

12 Barbić, J., Opći dio, op. cit. u bilj. 2, str. 649. O ulozi gospodarskog pojma koncerna na pravni pojam koncerna v. Bayer, W. op. cit. u bilj. 6, § 18, para. 29; Emmerich, V., op. cit. u bilj. 4, § 18 , para. 5,9 . Da je sam pojam poduzeća primarno gospodarski, a tek sekundarno pravni pojam v. Barbić, J., Opći dio, op. cit. u bilj. 2, str. 223 i dalje.

13 Barbić, J., Opći dio, op. cit. u bilj. 2, str. 649; Koch, J., op. cit. u bilj. 6, § 18, para. 8-19; Bayer, W, op. cit. u bilj. 6, § 18, para. 29-30; Emmerich, V., op. cit. u bilj. 6, § 18, para. 10-11.

14 Gorenc, V., op. cit. u bilj. 2, str. 1788.

15 Emmerich, V., op. cit. u bilj. 6, § 18, para. 9.

16 Barbić, J., Opći dio, op. cit. u bilj. 2, str. 650-651. 
društava - većinsko sudjelovanje - stvara oborivu presumpciju da između tih društava postoji odnos ovisnosti, a on pak stvara oborivu presumpciju da postoji faktični koncern. Iz izloženoga proizlazi da zakonom predviđeni oblici povezanih društava (čl. 473 ZTD) prvenstveno služe da bi olakšali utvrđivanje kada postoji koncern. Zbog toga se umjesto prava povezanih društava često koristi naziv koncernsko pravo. ${ }^{17}$

Potrebno je, ipak, imati na umu da je za mnoge tipične učinke faktičnog koncerna dovoljan već i odnos ovisnoga i vladajućeg društva, neovisno jesu li oni povezani i jedinstvenim vođenjem, odnosno može li se oboriti presumpcija faktičnog koncerna. Primjerice, za primjenu pravila o konsolidiranom izvješću o stanju društva, pravila o konsolidiranom godišnjem financijskom izvješću (čl. 250.b ZTD, čl. 23 Zakona o računovodstvu ${ }^{18}$ ) te pravila o odgovornosti kada nema ugovora o vođenju poslova društva (čl. 496-502 ZTD) dovoljno je da se radi o vladajućem i ovisnome društvu (čl. 496. ZTD). Zbog toga se smatra da je pojam ovisnosti od središnje važnosti za koncernsko pravo, čak i neovisno o tome postoji li „pravi“ koncern u smislu jedinstvenog vođenja. ${ }^{19}$ Zbog toga, uostalom, nije za očekivati da će se vladajuće ili ovisno društvo često upuštati u obaranje presumpcija faktičnog koncerna.

Kao što je već spomenuto, za odnos ovisnosti konstitutivno je da vladajuće društvo u ovisnome društvu može imati posredno ili neposredno prevladavajući utjecaj. Nije, dakle, nužno da prevladavajući utjecaj stvarno postoji, nego da vladajuće društvo ima mehanizme kojima bi takav utjecaj moglo vršiti. ${ }^{20}$ Smatra se, međutim, da mogućnost prevladavajućeg utjecaja mora proizlaziti iz organizacijskih pravila prava društva, odnosno ne bi bilo dovoljno da proistječe iz obveznopravnih ugovora ili isključivo gospodarske ovisnosti. ${ }^{21}$ Dovoljno je da je mogućnost prevladavajućeg utjecaja posredna. Klasičan primjer posrednog utjecaja je kada vladajuće društvo na čelu koncerna vrši utjecaj ne samo na društva u kojima ima većinu udjela (društva kćeri) nego i na društva u kojima društva kćeri imaju većinu udjela (društva unuke). ${ }^{22}$

Pojam prevladavajućeg utjecaja trebao bi označavati utjecaj na vođenje poslova ovisnoga društva. Visoki trgovački sud tako je našao da ,prevladavajućim utjecajem smatra se utjecaj vladajućeg društva na vođenje poslova i donošenje odluka u ovisnom društvu...". Prevladavajući utjecaj bi, dakle, morao ultimativno ovisiti općim pravilima prava društava koje omogućuju članu društva da utječe na društvo. ${ }^{23}$ Pri tome treba imati na umu razlike između dioničkih društava i društava s ograničenom odgovornošću.

U dioničkom društvu s dualističkim ustrojem organa uprava vodi poslove na vlastitu odgovornost (čl. 240 st. 1 ZTD). Iz toga se izvodi da u dioničkom društvu ne postoji hijerarhija među organima, odnosno da uprava nije dužna slijediti upute

17 Bayer, W., op. cit. u bilj. 6, § 15, para. 6 .

18 NN, br. 78/15, 134/15, 120/16.

19 Bayer, W., op. cit. u bilj. 6, § 17, para. 2.

20 VTS Pž 3289/2017-2 od 29.5.2017.; Barbić, J., Opći dio, op. cit. u bilj. 2, str. 643-644; Bayer, W., op. cit. u bilj. 6, § 17, para. 11.

21 Barbić, J., Opći dio, op. cit. u bilj. 2, str. 644; Koch, J., op. cit. u bilj. 6, § 17, para. 8; Emmerich, V., op. cit. u bilj. 6, § 17, para. 15; Bayer, W., op. cit. u bilj. 6, § 17, para. 21.

22 Emmerich, V., op. cit. u bilj. 6, § 17, para. 26-27; Krieger, G., op. cit. u bilj. 6, § 69, para. 49.

23 Emmerich, V., op. cit. u bilj. 6, § 17, para. 6. 
bilo glavne skupštine bilo nadzornog odbora. Glavna skupština nije ovlaštena donositi odluke iz područja vođenja poslova društva, a uprava bi ih u svakom slučaju trebala odbiti ako pozornošću urednog i savjesnog gospodarstvenika procijeni da nisu u interesu društva. ${ }^{24}$ Uprava je vezana odlukama glavne skupštine samo iznimno, kada je sama zatražila da glavna skupština odluči o pitanjima vođenja poslova, što je u vezi s nekim pitanjima kojima se u bitnome utječe na položaj članova u društvu uprava dužna učiniti. ${ }^{25}$ Imenovanje i opoziv članova uprave, također, ne ovise izravno o glavnoj skupštini, nego o nadzornom odboru (čl. 244 ZTD), s tim da nadzorni odbor može opozvati članove uprave samo ako postoji važan razlog (čl. 244 st. 2 ZTD). Osim toga, na nadzorni odbor se ne može prenijeti ovlast vođenja poslova (čl. 263 st. 5 ZTD). Čak i ako se statutom ili odlukom nadzornog odbora odredi da se određene vrste poslova mogu obavljati samo uz suglasnost nadzornog odbora, dana suglasnost ne predstavlja uputu kojom bi uprava bila vezana. ${ }^{26}$

Iz toga bi se moglo zaključiti da većinski dioničar putem glavne skupštine nikada ne može vršiti prevladavajući utjecaj na dioničko društvo. ${ }^{27}$ Glavna skupština ipak može utjecati na sastav uprave imenovanjem članova nadzornog odbora koji će pak imenovati članove uprave. Osim toga važan razlog za opoziv članova uprave predstavlja i izglasavanje nepovjerenja na glavnoj skupštini, osim ako je to učinjeno zbog očito neutemeljenih razloga (čl. 244 st. 2 ZTD). Većinski dioničar bi, dakle, putem glavne skupštine mogao imenovati članove nadzornog odbora $\mathrm{i}$ takvom nadzornom odboru pružiti mogućnost da na jednostavan način postojeće članove uprave zamijene novima. Iako bi takvi novi članovi uprave i sami bili dužni voditi poslove društva nezavisno o utjecaju glavne skupštine, jasno je da će oni u praksi ostati naklonjeni osobi kojoj mogu zahvaliti svoje imenovanje.

Zbog toga se koncernski pojam prevladavajućeg utjecaja proširuje s mogućnosti utjecaja na vođenje poslova društva na mogućnost poduzimanja mjera protiv ovisnoga društva ili osoba koje u njemu vode poslove. ${ }^{28}$ To je prepoznao i Visoki trgovački sud proširivši pojam prevladavajućeg utjecaja s utjecaja na vođenje poslova na mogućnost „vladajućeg društva da prema ovisnom društvu ili osobama koje u njemu vode poslove društva može primjenjivati određene mjere ili davati upute. ${ }^{\text {"29 }}$ Drugim riječima, iako, strogo gledano, većinski dioničar nema pravo utjecati na vođenje poslova društva, pravni sustav prepoznaje da do takvog utjecaja u stvarnosti lako može doći putem mjera koje većinski dioničar može poduzeti prema osobama koje vode poslove društva. ${ }^{30}$ Upravo u tome leži bit faktičnog koncerna - koncern je faktičan jer pravo društava omogućuje vladajućem društvu da stekne stvarnu, izvanpravnu mogućnost

24 Barbić, J., Dioničko društvo, op. cit. u bilj. 5, str. 777-778.

25 Barbić, J., Dioničko društvo, op. cit. u bilj. 5, str. 779-780.

26 Barbić, J., Dioničko društvo, op. cit. u bilj. 5, str. 779. To se može zaključiti i na temelju okolnosti da suglasnost nadzornog odbora ne oslobađa članove uprave njihove odgovornosti (čl. 252 st. 4 ZTD).

27 Bayer, W. op. cit. u bilj. 6, § 18, para. 20.

28 Barbić, J., Opći dio, op. cit. u bilj. 2, str. 644; Krieger, G., op. cit. u bilj. 6, § 69, para. 38-40.; Emmerich, V., op. cit. u bilj. 6, § 17, para. 6-7.

29 VTS Pž 3289/2017-2 od 29.5.2017.

30 Bayer, W., op. cit. u bilj. 6, § 17, para. 21. § 18, para. 20. 
vršiti odlučujući utjecaj na vođenje poslova društva.

Za razliku od toga, u monističkom ustroju dioničkog društva postoji hijerarhijski odnos između organa jer je upravni odbor, kojeg imenuje i opoziva glavna skupština (čl. 272.c, 272.e ZTD), ovlašten davati izvršnim direktorima obvezujuće upute. ${ }^{31}$ Mogućnost prevladavajućeg utjecaja većinskog dioničara proizlazi, dakle, već iz zakonskih odredbi.

U društvu s ograničenom odgovornošću uprava je dužna voditi poslove društva, među ostalim, u skladu s odlukama članova društva, uputama skupštine i nadzornog odbora (čl. 422 st. 2 ZTD). Uprava ipak ne bi smjela slijediti upute ako je odluka članova društva ništetna, najčešće zbog povrede propisa kojima se isključivo ili pretežito štite interesi vjerovnika (čl. 355 st. 1 toč. 3 , čl. 448 ZTD), primjerice odluka kojom se upravu upućuje na isplatu nakon nesposobnosti društva za plaćanje, odnosno prezaduženosti (čl. 251, čl. 431.c ZTD) ili na isplatu članovima društva imovine čija vrijednost odgovara iznosu temeljnog kapitala (čl. 4907 st. 1 ZTD). ${ }^{32}$ Ako odluka članova društva nije ništetna, uprava ju ne bi smjela odbiti izvršiti samo zbog toga što smatra da je štetna za društvo ili što je zbog drugih razloga pobojna. ${ }^{33}$ Hijerarhijska nadređenost članova društva upravi proizlazi, među ostalim i iz okolnosti da članovi društva mogu svojom odlukom u svako doba opozvati članove društva (čl. 424 st. 1 ZTD). U društvu s ograničenom odgovornošću mogućnost prevladavajućeg utjecaja većinskog člana društva, također dakle, proizlazi već iz zakonskih odredbi.

Naposljetku valja se osvrnuti na, tzv. kvalificirani faktični koncern. Iako za njegovo postojanje ne postoji posebna zakonska osnova, on je, po uzoru na njemačku sudsku praksu, prepoznat u hrvatskoj pravnoj teoriji kao koncern u kojem je faktično prevladavajući utjecaj vladajućeg društva u ovisnome društvu usporediv s utjecajem vladajućeg društva kod ugovora o vođenju poslova društva. ${ }^{34}$ Kvalificirani faktični koncern prepoznao je i Vrhovni sud kao koncern u kojem vladajuće društvo može „presudno“ utjecati na vođenje poslova ovisnoga društva. ${ }^{35} \mathrm{O}$ dopuštenosti tog koncerna će viti više govora u idućem podnaslovu.

\section{UČINCI FAKTIČNOG KONCERNA U ODNOSU VLADAJUĆEG I OVISNOG DRUŠTVA}

Prethodni podnaslov pokazao je da postojanje faktičnog koncerna proizlazi iz puke mogućnosti da vladajuće društvo vrši utjecaj na ovisno društvo. To, međutim, samo po sebi ne znači da je stvarno vršenje takvog utjecaja dopušteno. Dapače, sama činjenica da ima mogućnost vršiti prevladavajući utjecaj ne bi smjela vladajućem

31 Barbić, J., Dioničko društvo, op. cit. u bilj. 5, str. 1106.

32 Stephan, K-D.; Tieves, J. u: Münchener Kommentar zum GmbHG, Band 2, München, C. H. Beck, 2016, § 37. para. 118-120; slično i Barbić, J., Društvo s ograničenom odgovornošću, op. cit. u bilj. 5, str. 380-381.

33 Stephan, K-D.; Tieves, J., op. cit. u bilj. 32, § 37, para. 120; Barbić, J., Društvo s ograničenom odgovornošću, op. cit. u bilj. 5 , str. 381 .

34 Barbić, J., Opći dio, op. cit. u bilj. 2, str. 651-653; v. i Jurić, D., Odgovornost vladajućeg društva, op. cit. u bilj. 2, str. 525.

35 VSRH Revt 159/11-2 od 24.1.2012 i i VTS Pž-1760/02 od 15.4.2003. (sentenca na IUSinfo). 
društvu davati veća prava u pogledu vođenja poslova društva od onih koja imaju ostali članovi društva. U suprotnom bi opća pravila o granicama utjecaja članova društva (skupštine) na vođenje poslova društava kapitala bila cirkularna i diskriminirajuća. Cirkularnost bi proizlazila iz činjenice da svaki član koji utječe na vođenje poslova društva prethodno mora imati tu mogućnost. Kada bi, dakle, puka mogućnost ujedno i ovlašćivala na vođenje poslova, to bi značilo da je svakom članu dozvoljeno utjecati na vođenje poslova društva. S obzirom na to da bi svatko tko može ujedno i smio voditi poslove društva, izbrisala bi se razlika između normativnog i faktičnog, a time i potreba za posebnim pravnim pravilom.

Pravila o granicama utjecaja na vođenje poslova društva mogla bi biti diskriminirajuća prema članovima društva koji sami nisu društva, najčešće fizičkim osobama. Pravila o povezanim društvima i faktičnom koncernu se, naime, primjenjuju samo na odnose više društava (čl. 473, 476 ZTD). ${ }^{36}$ Kada bi vladajuće društvo bilo dovedeno u povoljniji položaj u odnosu na vladajuće fizičke osobe, došlo bi do povrede čl. 49. st. 2 Ustava Republike Hrvatske, ${ }^{37}$ prema kojemu država osigurava svim poduzetnicima jednak položaj na tržištu.

Zbog toga ne začuđuje da su učinci faktičnog koncerna - pravila o odnosima vladajućeg i ovisnog društva - prvenstveno ograničavajućeg karaktera. Njihova je primarna svrha spriječiti preveliki utjecaj vladajućeg društva i zaštititi manjinske članove i vjerovnike ovisnoga društva. ${ }^{38} \mathrm{U}$ pravnoj teoriji zbog toga se ponekad tvrdi da zakonodavac faktični koncern ne odobrava nego trpi. ${ }^{39}$ Osnovno pravilo iz čl. 496 st. 1 ZTD predviđa da ako nije sklopljen ugovor o vođenju poslova društva, vladajuće društvo ne smije koristiti svoj utjecaj da ovisno društvo uputi na to da poduzme štetne pravne poslove ili da poduzme ili propusti radnje na svoju štetu, osim ako se vladajuće društvo obveže da će ovisnome društvu nadoknaditi štetu koja bi mu time nastala.

Izložena odredba može se razložiti na dva osnovna dijela. Prema prvome od njih vladajuće društvo ne smije koristiti svoj utjecaj da ovisno društvo uputi na poduzimanje radnji koje su štetne za ovisno društvo. Pojam upute treba shvatiti u širokom smislu kao svaku radnju koju bi ovisno društvo moglo shvatiti kao izraz želje vladajućeg društva da ono postupi na određeni način. ${ }^{40}$ To treba ocjenjivati objektivno iz perspektive ovisnoga društva, neovisno je li vladajuće društvo imalo namjeru davati obvezujuće upute. ${ }^{41}$

Štetnost se shvaća kao svako smanjenje ili ugrožavanje imovine društva. ${ }^{42}$ Štetnost se utvrđuje usporedbom s hipotetskim ponašanjem fiktivnog, neovisnog,

36 Barbić, J., Opći dio, op. cit. u bilj. 2, str. 637.

37 NN, br. 56/1990, 135/1997, 113/2000, 28/2001, 76/2010, 5/2014.

38 Barbić, J., Opći dio, op. cit. u bilj. 2, str. 656, gdje kaže da je riječ o zaštitnom pravilu.; Habersack, M., op. cit. u bilj. 6, § 311, para. 1.; Altmeppen, H., op. cit. u bilj. 6, § 311, para. 3 i dalje.

39 Altmeppen, H., op. cit. u bilj. 6, § 311, para. 26.

40 Altmeppen, H., op. cit. u bilj. 6, § 311, para. 76.; Koch, J., op. cit. u bilj. 6, § 311, para. 13.

41 Barbić, J., Opći dio, op. cit. u bilj. 2, str. 658; Altmeppen, H., op. cit. u bilj. 6, § 311, para. 80.; Koch, J., op. cit. u bilj. 6, § 311, para. 13.

42 Barbić, J., Opći dio, op. cit. u bilj. 2, str. 658. 
uredno vođenog društva, koje je, uz iznimku ovisnosti, istovjetno ovisnome društvu. ${ }^{43}$ Na taj se način mogu uzeti u obzir i specifičnosti konkretnog ovisnoga društva, osim, naravno, onih koje proizlaze iz odnosa ovisnosti. ${ }^{44}$ Ako bi, dakle, uredan i savjestan voditelj poslova nekoga nezavisnog društva ušao u takav pravni posao ili bi poduzeo ili propustio istu takvu radnju, ne samo da vladajuće društvo i njegovi zakonski zastupnici neće biti odgovorni za štetu, nego se ne može ni govoriti o radnji štetnoj po ovisno društvo (čl. 501 st. 3 ZTD). ${ }^{45}$ Štetnost radnje ocjenjuje se ex ante, u trenutku poduzimanja radnje. ${ }^{46}$ Nije nužno da se štetnost može kvantificirati, ${ }^{47}$ zbog čega se navedeni pojam ne podudara s pojmom štete iz čl. 1046 Zakona o obveznim odnosima (dalje: $\mathrm{ZOO})^{48} .{ }^{49}$

Prvi dio čl. 496 st. 1 ZTD oživotvoruje opće pravilo prema kojemu član društva ne smije uputiti upravu društva da poduzme pravne radnje na štetu društva. Njegova je svrha zaštititi vjerovnike društva i manjinske dioničare društva. ${ }^{50} \mathrm{U}$ dioničkom društvu koje je ustrojeno dualistički to proizlazi već iz nehijerarhijskog odnosa organa i stroge odvojenosti njihovih nadležnosti. Isto vrijedi i za društvo $\mathrm{s}$ ograničenom odgovornošću usprkos hijerarhijskoj nadređenosti skupštine i njezine ovlasti da upravi daje obvezujuće upute, kao i za monistički ustrojeno dioničko društvo, u kojem je upravni odbor hijerarhijski iznad izvršenih direktora. Temeljna obveza svih članova društva je, naime, obveza na lojalno postupanje prema društvu i drugim članovima koja, između ostalog, zabranjuje nanošenje štete društvu. ${ }^{51}$

Prvi dio čl. 496 ZTD-a izravno se odražava na ponašanje organa i vladajućeg i ovisnog društva, prvenstveno njihovog poslovodnog organa, najčešće uprave. ${ }^{52}$ Uprava vladajućeg društva nije ovlaštena davati ovisnome društvu upute koje su za njega štetne, a ako bi ih ipak dala, uprava ovisnoga društva ne bi ih smjela provesti..$^{53}$ Kao protuteža tome, uprava vladajućeg društva nema dužnost voditi poslove ovisnoga društva, ${ }^{54}$ pa shodno tome za to nije ni odgovorna. Jednako tako nadzorni odbori ovisnog i vladajućeg društva nadziru poslovanje isključivo vlastitoga društva. U tom kontekstu, nadzorni odbor vladajućeg društva morao bi nadzirati daje li uprava toga društva štetne upute ovisnome društvu, a nadzorni odbor ovisnoga društva provodi li njegova uprava takve upute. Ovlasti i odgovornost organa društava u faktičnom

43 Barbić, J., Opći dio, op. cit. u bilj. 2, str. 658, 671; Habersack, M., op. cit. u bilj. 6, § 311, para. $41,53$.

44 Habersack, M., op. cit. u bilj. 6, § 311, para. 41; Müller, H-F., op. cit. u bilj. 6, § 311, para. 30.

45 Habersack, M., op. cit. u bilj. 6, § 311, para. 40.

46 Müller, H-F., op. cit. u bilj. 6, § 311, para. 29; Habersack, M., op. cit. u bilj. 6, § 311, para. 44.

47 Barbić, J., Opći dio, op. cit. u bilj. 2, str. 658, 659; Koch, J. op. cit. u bilj. 6, § 311, para. 156.

48 NN 35/2005, 41/2008, 125/2011, 78/2015, 29/2018.

49 Barbić, J., Opći dio, op. cit. u bilj. 2, str. 658; Koch, J., op. cit. u bilj. 6, § 311, para. 26; Altmeppen, H., op. cit. u bilj. 6, § 311, para. 156 (iako on to relativizira, v. para. 179 i dalje).

50 Koch, J., op. cit. u bilj. 6, § 311, para. 24, 1.

51 Barbić, J., Društvo s ograničenom odgovornošću, op. cit. u bilj. 5, str. 235.

52 Habersack, M., op. cit u bilj. 6, § 311, para. 1.

53 Altmeppen, op. cit. u bilj. 6, § 311, para. 464-465.

54 Koch, J., op.cit. u bilj. 6, § 76, para. 47; Spindler, Gerald u: Goette, W.; Habersack, M. (ur.), Münchener Kommentar zum Aktienrecht, Band 2, München, C. H. Beck/Franz Vahlen, 2014., $\S 76$, para. 42 i dalje. 
koncernu bit će detaljnije objašnjeni u idućim podnaslovima. ${ }^{55}$

Drugi dio čl. 496 st. 1 ZTD predstavlja iznimku od općeg pravila o zabrani štetnih uputa ovisnome društvu. Vladajuće društvo je, naime, ovlašteno davati štetne upute ovisnome društvu ako se obveže da će ovisnome društvu nadoknaditi štetu koja bi mu time nastala. Štetu mora nadoknaditi najkasnije do kraja poslovne godine u kojoj je društvu počinjena šteta ili u tom razdoblju ovisnome društvu mora dati odgovarajući zahtjev na nadoknadu štete (čl. 496 st. 2 ZTD). Šteta mora biti nadoknađena putem konkretnih, u novcu izrazivih, prednosti. Ne bi dostajale apstraktne prednosti zbog same činjenice postojanja koncerna. ${ }^{56}$ Bitno je da se nadoknada štete, odnosno zahtjev na nadoknadu štete mogu iskazati u istim godišnjim financijskim izvješćima u kojima se iskazuje šteta. ${ }^{57}$

Iako se govori o ,nadoknadi štete“, treba primijetiti da se ne radi o općem pravilu odštetnoga prava o naknadi štete (čl. 1045. ZOO). Opće pravilo o naknadi štete, naime, podrazumijeva da je šteta uzrokovana protupravnom radnjom. S druge strane, iz čl. 496 ZTD proizlazi da odgovarajuća nadoknada štete isključuje protupravnosti, odnosno da je u tom slučaju vladajuće društvo ovlašteno davati štetne upute ovisnome društvu. To je još jasnije iz čl. 501 st. 1. ZTD-a prema kojemu vladajuće društvo mora ovisnome društvu naknaditi štetu prouzročenu štetnim uputama, samo ako štetu ne nadoknadi do kraja poslovne godine niti dade ovisnome društvu pravni zahtjev da mu se šteta nadoknadi. Drugim riječima, vladajuće društvo ima priliku spriječiti protupravnost štetnih odgovarajućom nadoknadom štete do kraja iste poslovne godine, a tek nakon toga nastupa njegova odgovornost za naknadu štete. ${ }^{58}$ Moglo bi se kazati da je ovdje obveza „naknade štete“ zapravo naknada (oblik „protučinidbe“, makar samo davanje uputa nema činidbu na strani ovisnog društva) vladajućeg društva koju daje ovisnome društvu jer mu daje upute koje su za ovisno društvo štetne.

Izložena distinkcija nema samo teoretske, nego i praktične posljedice. Kada bi zbog upute vladajućeg društva koja je prouzročila štetu ovisnome društvu, ovisno društvo stjecalo zahtjev na naknadu štete, ono bi moglo zahtijevati od vladajućeg društva naknadu štete odmah od trenutka njezinog nastanka (čl. 1086 ZOO). Pravilo čl. 496 ZTD dovodi, međutim, do toga da ovisno društvo nema nikakav zahtjev prema vladajućem društvu do kraja poslovne godine nego se vladajućem društvu ostavlja mogućnost da spriječi protupravnost svoje radnje. Tek ako tu mogućnost ne iskoristi, protekom poslovne godine ovisno društvo stječe zahtjev na naknadu štete.

Koncernska pravila o nadoknadi štete iz čl. 496 st. 1 ZTD imaju prednost ne samo pred pravilima o naknadi štete nego i pred načelom očuvanja kapitala društva (čl. 217, 407 ZTD), odnosno dužnosti članova društva da vrate nedopuštena primanja (čl. 224, 407 ZTD). ${ }^{59}$ Iz okolnosti da, pod uvjetom da nadoknadi štetu, vladajuće društvo smije ovisnome društvu davati upute na poduzimanje štetnih radnji može

55 Podnaslov 4. i 5.

56 Altmeppen, H., op. cit. u bilj. 6, § 311, para. 306, 340; Müller, H-F., op. cit. u bilj. 6, § 311, para. 50.

57 Barbić, J., Opći dio, op. cit. u bilj. 2, str. 661-662.

58 Altmeppen, H., op. cit. u bilj. 6, § 311, para. 305 i dalje.

59 Barbić, J., Opći dio, op. cit. u bilj. 2, str. 657; Habersack, M., op. cit. u bilj. 6, § 311, para. 82; Altmeppen, H., op. cit. u bilj. 6, § 311, para. 458. 
se, naime, zaključiti da takve radnje ne vrijeđaju očuvanje kapitala. Kad bi to bio slučaj, članovi društva bili bi dužni odmah vratiti zabranjena plaćanja što bi oduzelo vladajućem društvu priliku da nadoknadi štetu do kraja poslovne godine.

U hrvatskoj pravnoj teoriji ${ }^{60} \mathrm{i}$ sudskoj praksi ${ }^{61}$ može se susresti stav da bi, ako su ispunjene određene subjektivne pretpostavke, upute vladajućeg društva ovisnome društvu na poduzimanje štetnih radnji mogle dovesti do proboja pravne osobnosti zbog zlouporabe prava. ${ }^{62}$ Neovisno o tome što je zlouporabu prava iz čl. 10 st. 3 ZTD ispravnije shvatiti kao zlouporabu u objektivnom smislu, ${ }^{63}$ trebalo bi biti oprezan prilikom primjene instituta proboja pravne osobnosti. Ako se, naime, uputa vladajućeg društva sastojala u tome da ovisno društvo njemu izvrši isplatu iz imovine ovisnoga društva, povreda se može učinkovito sanirati već i zahtjevom na povrat nedopuštenih primanja (čl. 224, 407 ZTD). Za razliku od odgovornosti s naslova proboja pravne osobnosti, po kojoj član društva (vladajuće društvo) odgovara solidarno i neograničeno za obveze društva, ${ }^{64}$ odgovornost za povrat nedopuštenih primanja manje je tegotna po člana društva jer je ograničena na vrijednost nedopuštenih primanja.

Drugi dio čl. 496 st. 1 ZTD predstavlja, dakle, posebnost koncernskog prava u odnosu na opća pravila prava društava. Vladajuće društvo stječe, tzv. koncernski privilegij ${ }^{65} \mathrm{da}$, pod određenim uvjetima, može davati ovisnome društvu štetne upute. Takav se privilegij objašnjava posebnim položajem vladajućeg društva koje je, može se pretpostaviti, uložilo značajna sredstva u stjecanje većinskog položaja u ovisnome društvu. Taj se privilegij, međutim, može opravdati samo ako ne dovodi manjinske članove i vjerovnike ovisnoga društva u lošiji položaj. ${ }^{66}$ To je moguće samo ako po proteku poslovne godine oni neće biti u nepovoljnijem položaju nego da nije bilo štetne upute. To je pak moguće samo ako je u trenutku davanje štetne upute bilo izgledno da vladajuće društvo može nadoknaditi štetu ovisnome društvu, odnosno da mu može dati zahtjev za nadoknadu štete, koji se u bilanci može iskazati u nominalnom iznosu. ${ }^{67}$

Koncernska pravila, dapače, u nekim aspektima stavljaju manjinske članove i vjerovnike ovisnoga društva u povoljniji položaj. Ako vladajuće društvo ne nadoknadi štetu ovisnome društvu do kraja poslovne godine ono će biti objektivno odgovorno za štetu (čl. 501. ZTD) ${ }^{68}$ a ne prema općim pravilima, samo ako to učini s nakanom (čl. 273 st. 1 . ZTD).

Na temelju provedene analize može se zaključiti da dva dijela odredbe čl. 496 st. 1. ZTD-a obavljaju različitu funkciju. Svrha prvoga dijela je zaštita manjinskih članova i

60 Braut Filipović, M., op. cit. u bilj. 2, str. 822.

61 VSRH Revt 159/11-2 od 24.1.2012.

62 Braut Filipović, M., op. cit. u bilj. 2, str. 822, traži postojanje namjere, odnosno svijesti o zloporabi. Vrhovni sud također spominje subjektivnu preptostavku, ali sugerira da pod time misli samo na to da je ovisno društvo korišteno kao sredstvo ostvarenja ciljeva koji nisu bili dopušteni vladajućem društvu, što se ne bi moglo smatrati subjektivnom pretpostavkom.

63 O mogućnosti da se zlouporaba objektivizira v. Barbić, J., Opći dio, op. cit. u bilj. 2, str. 300.

64 Barbić, J., Opći dio, op. cit. u bilj. 2, st. 300.

65 Habersack, M., op. cit u bilj. 6, § 311, para. 2.

66 Altmeppen, H., op. cit. u bilj. 6, §311, para. 305 i dalje.

67 Altmeppen, H., op. cit. u bilj. 6, § 311, para. 465, 471.

68 Za detaljniju raspravu v. podnaslov 4. 
vjerovnika ovisnoga društva. Svrha drugoga dijela je izići u susret vladajućem društvu, ovlašćujući ga da pod iznimnim okolnostima upućuje ovisno društvo na poduzimanje pravnih radnji koje su štetne za ovisno društvo. Takvo privilegiranje vladajućeg društva je, međutim, pažljivo uravnoteženo njegovom dužnošću da nadoknađuje štetu ovisnome društvu do kraja poslovne godine, a ako to ne učini da mu odgovara prema općim pravilima odštetnoga prava ${ }^{69} \mathrm{Za}$ učinkovito ostvarivanje spomenute ravnoteže odlučujući je položaj članova organa kako vladajućeg tako i ovisnoga društva. Zbog toga će se u idućim podnaslovima detaljnije razmotriti kako se pravila o odnosima vladajućeg i ovisnoga društva odražavaju na njihovu odgovornost.

Kao što je objašnjeno u prethodnom podnaslovu, hrvatsko pravo poznaje kvalificirani faktični koncern. To, međutim, ne znači da hrvatsko pravo dozvoljava njegovo postojanje. Granice dopuštenog djelovanja u faktičnom koncernu su na iscrpan način postavljene pravilom o granicama utjecaja iz čl. 496. ZTD-a. Prevladavajući utjecaj vladajućeg društva u kvalificiranom faktičnom koncernu usporediv je $\mathrm{s}$ utjecajem vladajućeg društva kod ugovora o vođenju poslova društva upravo jer se, zbog njegove trajnosti i intenziteta, pojedine štetne radnje više ne mogu izdvojeno promatrati. ${ }^{70}$ To onda znači da se vladajuće društvo više ne može obvezati ovisnome društvu naknaditi štetu koja mu je nastala pojedinom radnjom (čl. 496 st. 1. ZTD-a), niti uprava može izvijestiti o pojedinim radnjama koje je ovisno društvo poduzelo prema uputama vladajućeg društva (čl. 497 ZTD).

Budući da je protivan prisilnoj odredbi čl. 496 ZTD, u hrvatskom, jednako kao i u njemačkom pravu, kvalificirani faktični koncern nije dopušten. ${ }^{71}$ Isključiva funkcija tog instituta je - kada dođe do povrede koncernskih pravila - zaštititi manjinske članove i vjerovnike ovisnoga društva na način na koji bi bili zaštićeni da postoji ugovorni koncern. Na kvalificirani faktični koncern zbog toga se na odgovarajući način primjenjuju odredbe o preuzimanju gubitka (čl. 489. ZTD-a), primjerenoj naknadi i otpremnini vanjskim dioničarima (čl. 491, čl. 492. ZTD-a) te posebnoj odgovornosti zakonskih zastupnika vladajućeg društva i članova ovisnoga društva (čl. 494, čl. 495 ZTD-a). To je izgleda prepoznao i Vrhovni sud upućujući da je glavni učinak kvalificiranog faktičnog koncerna da je vladajuće društvo obvezno pokrivati gubitke ovisnoga društva. ${ }^{72}$

Valja napomenuti da je za društvo s ograničenom odgovornošću novija njemačka sudska praksa odustala od zaštite vjerovnika društva putem kvalificiranog faktičnog koncerna ${ }^{73}$ među ostalim zbog toga što specifična koncernska zaštita nije bila u stanju

69 Primjerice Grigoleit, H.-C. u: Grigoleit, H.-C. (ur.), Aktiengesetz Kommentar, München, C. H. Beck, 2013, § 317, para. 4.

70 Müller, H.-F., op. cit. u bilj. 6, Vorbem. § 311-318, para. 25; Habersack, M., op. cit. u bilj. 6, Anh. § 317 AktG, para. 5-5a; Bayer, W., op. cit. u bilj. 6, § 18, para. 11.

71 Müller, H.-F., op. cit. u bilj. 6, Vorbem. § 311-318, para. 28.

72 VSRH Revt 159/11-2 od 24.1.2012 i i VTS Pž-1760/02 od 15.4.2003. (sentenca na IUSinfo).

73 Altmeppen, H., Grundlegend Neues zum „qualifiziert faktischen“ Konzern und zum Gläubigerschutz in der Einmann-GmbH, ZIP 2001, str. 1837; Habersack, M., op. cit. u bilj. 6, Anh. § 317 AktG, para. 4; Liebscher, Thomas u: Fleischer, H.; Goette, W. (ur.), Münchener Kommentar zum GmbHG, Band 1, München, C. H. Beck, 2018, Anh. § 13, para. 519 i dalje. 
zaštititi vjerovnike društva od utjecaja članova u situacijama kada ne postoji koncern. ${ }^{74}$ Umjesto kvalificiranog faktičnog koncerna njemački Vrhovni sud opredijelio se za konstrukciju odgovornosti članova društva zbog uništenja opstojnosti društva (Existenzvernichtungshaftung), koja se, prema najnovijim presudama, svodi na opća pravila deliktne odgovornosti. ${ }^{75}$ Pri tome treba imati na umu da se u njemačkom pravu koncernske odredbe o odgovornosti kada nema ugovora o vođenju poslova društva ( $\S$ 311-318 njemačkog Zakona o dioničkim društvima, koje odgovaraju čl. 496-502 ZTD) niti na odgovarajući način ne primjenjuju na društvo s ograničenom odgovornošću. ${ }^{76}$

U njemačkoj pravnoj teoriji, međutim, prevladava mišljenje da kvalificirani faktični koncern zadržava svoju funkciju za dioničko društvo u kojemu su vjerovnici društva dovoljno zaštićeni općim pravilima prava društava i na koje se primjenjuju spomenute odredbe o odgovornosti kada nema ugovora o vođenju poslova društva. ${ }^{77}$ To ostavlja mogućnost da i u hrvatskom pravu kvalificirani faktični koncern nastavi postojati i za dioničko društvo i za društvo s ograničenom odgovornošću jer se čl. 496-502. ZTD-a primjenjuju na oba društva kapitala. Ostaje, naravno, vidjeti kakav će stav zauzeti hrvatska sudska praksa s obzirom na konkretne okolnosti pojedinih slučajeva.

\section{ODGOVORNOST ČLANOVA ORGANA VLADAJUĆEG DRUŠTVA U FAKTIČNOM KONCERNU}

Članovi organa vladajućeg društva su, prema općim pravilima, dužni voditi poslove, odnosno nadzirati vođenje poslova vladajućeg društva pozornošću urednog i savjesnog gospodarstvenika, a ako povrijede tu dužnost bit će odgovorni za štetu koja je nastala vladajućem društvu (čl. 252, čl. 272, čl. 272.k, čl. 272.1 st. 9, čl. 430, čl. 439. ZTD-a). Pozornost urednog i savjesnog gospodarstvenika, naravno, obuhvaća i zastupanje interesa vladajućeg društva u ovisnome društvu, prvenstveno sudjelovanjem i glasovanjem na glavnom skupštini. Ništa od toga, međutim, ne predstavlja specifičnost faktičnog koncerna.

Ostaje razmotriti mogu li članovi organa vladajućeg društva biti odgovorni za štetu nastalu ovisnome društvu i po kojoj osnovi. Ishodišna točka pravna je samostalnost vladajućeg i ovisnog društva. ${ }^{78}$ Budući da vladajuće društvo kao član ovisnoga društva nije ovlašteno voditi njegove poslove, ni uprava vladajućeg društva

74 Altmeppen, H., op. cit. u bilj. 73, str. 1837-1838; Lieder, Jan, u: Heidinger, A.; Leible, S.; Schmidt, J. (ur.), Kommentar zum GmbHG, Band 1, München, C. H. Beck, 2017, § 13, para. 421.

75 Liebscher, op. cit. u bilj. 73, Anh. § 13, para. 522.; Habersack, op. cit. u bilj. 6, Anh. § 317, para. 4.

76 Altmeppen, H., op. cit. u bilj. 6, Vorbem $\S 311$, para. 78; Habersack, op. cit. u bilj. 6, Anh. § 318 , para. 6.

77 Habersack, op. cit. u bilj. 6, Anh. § 317, para. 5-5a; Bayer, W., op. cit. u bilj. 6, § 18, para. 11-14; Müller, H.-F., op. cit. u bilj. 6, Vorbem. § 311-318, para. 25. Drukčije Altmeppen, H., op. cit. u bilj. 6, Anh. § 317, para. 13 i dalje.

78 VSRH Revt 60/04-2 od 6.10.2004.; VSRH Revr 344/08-2 od 17.6.2009.; VSRH Revt 159/11-2 od 24.1.2012.; VTS Pž-1934/06-3 od 22.4.2009. 
ne duguje pozornost urednog i savjesnog gospodarstvenika ovisnome društvu. ${ }^{79}$ Uprava vladajućeg društva bi prema općim pravilima eventualno mogla biti odgovorna naknaditi štetu vladajućem društvu koja je nastala zbog toga što je vladajuće društvo bilo dužno podmiriti štetu koju je povredom obveze lojalnosti prouzročilo ovisnome društvu. Primjerice, ako uprava vladajućeg društva na skupštini ovisnoga društva pomogne donijeti odluku koja je štetna po ovisno društvo, ovisno društvo bi moglo imati tražbinu na naknadu štete prema vladajućem društvu, a vladajuće društvo prema članovima uprave. Drugim riječima, izravna odgovornost članova organa vladajućeg društva prema ovisnome društvu ne može se izvesti iz općih pravila prava društava.

Odgovornost članova organa vladajućeg društva je, međutim, predviđena posebnom zakonskom odredbom. Ona se naslanja na osnovno pravilo o odgovornosti samog vladajućeg društva. Čl. 501 st. 1 . ZTD-a predviđa da ako vladajuće društvo potakne ovisno društvo, s kojim nema ugovor o vođenju poslova društva, da poduzme pravne poslove ili radnje, odnosno da propusti takve radnje na štetu ovisnog društva, a da vladajuće društvo štetu stvarno ne nadoknadi do kraja poslovne godine niti dade ovisnome društvu pravni zahtjev da mu se šteta nadoknadi, vladajuće društvo mora ovisnome društvu nadoknaditi svu štetu koja iz toga proizađe. Na to se nadovezuje čl. 501 st. 2. ZTD-a, prema kojem, pored vladajućega društva, odgovaraju kao solidarni dužnici i zakonski zastupnici društva, koji su uputili ovisno društvo na to da obavi pravni posao ili da poduzme, odnosno propusti da poduzme neke radnje. Ne bi bili odgovorni članovi organa ovisnoga društva koji nisu zakonski zastupnici - članovi nadzornog odbora ili neizvršni direktori. ${ }^{80}$

Riječ je o specifičnom obliku koncernske odgovornosti koja se ne može svesti na opća pravila o deliktnoj odgovornosti i odgovornosti zbog povrede obveze lojalnosti. ${ }^{81}$ Njezina je svrha pružiti manjinskim članovima i vjerovnicima ovisnoga društva pojačanu zaštitu ${ }^{82}$ i na taj način uravnotežiti relativno nepovoljni položaj u kojemu se nalaze zbog postojanja faktičnog koncerna.

Pretpostavke odgovornosti vladajućeg društva i njegovih zakonskih zastupnika uglavnom se podudaraju s pretpostavkama nedopuštenosti uputa vladajućeg društva iz čl. 496. ZTD-a. Vladajuće društvo će biti odgovorno ako je uputilo ovisno društvo da poduzme radnju koja je za njega bila štetna i ako nije nadoknadilo štetu do kraja poslovne godine. Prema čl. 501. st. 3 ZTD-a vladajuće društvo neće biti dužno naknaditi štetu ako bi uredan i savjestan voditelj poslova nekoga nezavisnog društva ušao u takav pravni posao ili bi poduzeo ili propustio istu takvu radnju. $U$ tom je kontekstu primjenjivo kao pravni standard i pravilo poslovne prosudbe ${ }^{83} \mathrm{Ta}$ se odredba, međutim, obično shvaća ne kao test za isključenje krivnje nego kao test za isključenje štetnosti radnje. ${ }^{84}$ Drugim riječima, ako bi uredan i savjestan voditelj poslova nekoga nezavisnog društva poduzeo istu radnju ne može se govoriti o štetnoj

79 Koch, J., op. cit. u bilj. 6, § 76, para. 47; Spindler, G., op. cit. u bilj. 54, § 76, para. 42 i dalje.

80 Barbić, J., Opći dio, op. cit. u bilj. 2, str. 670.

81 Habersack, op. cit. u bilj. 6, § 317, para. 11; Koch, J., op. cit. u bilj. 6, § 317, para. 5.

82 Barbić, J., Opći dio, op. cit. u bilj. 2, str. 669; Habersack, op. cit. u bilj. 6, § 317, para. 2.

83 Habersack, M., op. cit. u bilj. 6, § 311, para. 40.

84 Habersack, M., op. cit. u bilj. 6, § 311, para. 40; Krieger, G., op. cit. u bilj. 6, § 70, para. 131; drukčije Altmeppen, H., op. cit. u bilj. 6, § 317, para. 10. 
radnji, čime dakako uopće otpada i pitanje odgovornosti.

Osobito je zanimljivo pitanje temelji li se takva odgovornost na krivnji vladajućeg društva i njegovih zakonskih zastupnika ili se radi o objektivnoj odgovornosti. U pravnoj teoriji prevladava mišljenje da se za odgovornost vladajućeg društva i njegovih zakonskih zastupnika ne traži krivnja, čak ni obična nepažnja. ${ }^{85}$ Objektivna odgovornost opravdava se specifično koncernskom zaštitom manjinskih članova i vjerovnika ovisnoga društva te potrebom za uravnoteženjem privilegija koje vladajuće društvo ima kroz mogućnost da, uz nadoknadu štete, daje ovisnome društvu štetne upute. ${ }^{86}$

S takvim mišljenjem bi se trebalo složiti samo u pogledu odgovornosti vladajućeg društva. Objektivna odgovornost tada služi kao protuteža koncernskog privilegija davanja štetnih uputa. Odgovornost zakonskih zastupnika vladajućeg društva bi, međutim, trebalo tumačiti u skladu s općim pravilima o odgovornosti za štetu članova uprave, prema kojoj članovi uprave odgovaraju na temelju pretpostavljene krivnje, konkretno obične nepažnje (čl. 252 st. 2 ZTD). ${ }^{87}$ Zakonski zastupnici vladajućeg društva nisu, naime, korisnici koncernskog privilegija. Osim toga, teško bi se moglo opravdati da članovi uprave vladajućeg društva strože odgovaraju za štetu počinjenu ovisnome društvu, nego za onu počinjenu vladajućem društvu čije su poslove dužni voditi. ${ }^{88}$ Naposljetku i odgovornost na temelju pretpostavljene krivnje trebala bi biti dovoljno „stroga“ da prisili članove uprave na oprez prilikom davanja uputa ovisnome društvu.

Vjerovnik zahtjeva na naknadu štete je ponajprije samo ovisno društvo. Čl. 501 st. 1. ZTD-a predviđa da zahtjev za naknadu štete mogu pojedinačno postaviti i članovi društva koji su pretrpjeli štetu neovisnu o šteti koja im je prouzročena štetom počinjenom društvu. Riječ je o konkretizaciji općih uvjeta pod kojima članovi društva mogu imati zahtjev na naknadu štete prema članovima organa društva (v. čl. 273 st. 1 ZTD). Članovi društva, naime, ne mogu postaviti zahtjev prema članovima organa društva na naknadu, tzv. refleksne štete, jer bi u tom slučaju postojala opasnost da štetnik, član organa društva, dvostruko naknadi štetu (članu društva i društvu), a da se član društva dvostruko namiri (naknadom štete koju je dobio od štetnika i povećanjem vrijednosti udjela nakon što štetnik naknadi štetu društvu).

U pogledu odgovornosti zakonskih zastupnika čl. 501 st. 4. ZTD-a upućuje na odgovarajuću primjenu čl. 494 st. 3-5. ZTD-a koji uređuju odgovornost zakonskih zastupnika vladajućeg društva u ugovornom koncernu. Od tih pravila posebno vrijedi istaknuti odredbu prema kojoj svaki član društva može, ali samo u korist društva, postaviti zahtjev za naknadu štete (čl. 494 st. 4 ZTD). Riječ je o specifičnom obliku

85 Koch, J., op. cit. u bilj. 6, § 317, para. 5, 14; Habersack, op. cit. u bilj. 6, § 317, para. 7, 11; Müller, H.-F., op. cit. u bilj. 6, § 317, para. 4; izgleda i Barbić, J., op. cit. u bilj. 2, str. 670; Grigoleit, C.-H.; op. cit. u bilj. 69, § 317, para. 4 samo za odgovornost vladajućeg društva, a izgleda i Moslavac, B., op. cit. u bilj. 2, str. 6; drukčije Altmeppen, H., op. cit. u bilj. 6, § 317, para. 29.

86 Koch, J., op. cit. u bilj. 6, § 317, para. 5, Grigoleit, C.-H.; op. cit. u bilj. 69, § 317, para. 4.

87 Grigoleit, C.-H.; op. cit. u bilj. 69, § 317, para. 13.

88 Slično Grigoleit, C.-H.; op. cit. u bilj. 69, § 317, para. 13. 
članskog prava actio pro socio ${ }^{89}$ koji prema općim pravilima prava društava imaju samo članovi društava osoba i društva s ograničenom odgovornošću. ${ }^{90}$ Radi pojačane potrebe za zaštitom manjinskih članova i vjerovnika ovisnoga društva, u faktičnom koncernu takav zahtjev imaju i dioničari. U hrvatsko pravo društava actio pro socio uveden je iz njemačkog prava u kojemu je on dio šireg instituta procesnog namjesnišstva. ${ }^{91}$ Iako hrvatska procesna teorija ne poznaje općeniti institut procesnog namjesništva, ${ }^{92}$ izgleda da je actio pro socio kao njegov specifični oblik prihvaćen i u pravnoj teoriji ${ }^{93}$ i u sudskoj praksi. ${ }^{94}$

Može se, dakle, zaključiti da za odgovornost zakonskih zastupnika vladajućeg društva prema ovisnome društvu moraju biti ispunjene slične pretpostavke kao i prema općim pravilima za odgovornost članova organa društva (čl. 252 ZTD-a). U tom bi se smislu moglo reći da, barem u kontekstu odgovornosti, koncernska pravila nameću zakonskim zastupnicima vladajućeg društva obvezu vođenja poslova ovisnoga društva pozornošću urednog i savjesnog gospodarstvenika. To, dakako, ne znači da su zakonski zastupnici vladajućeg društva ovlašteni voditi poslove ovisnoga društva u smislu pravila statusnoga prava.

\section{ODGOVORNOST ČLANOVA ORGANA OVISNOGA DRUŠTVA U FAKTIČNOM KONCERNU}

Pravila o faktičnom koncernu sadrže posebne odredbe o odgovornosti članova organa ovisnoga društva ovisnome društvu. Prema čl. 502 st. 1. ZTD-a članovi uprave, odnosno izvršni direktori ovisnoga društva, odgovorni su ako, povrijedivši svoje obveze, u izvješću o odnosima ovisnoga društva s povezanim društvima propuste navesti štetne pravne poslove ili štetne radnje ili ne navedu da je društvo s tim pravnim poslovima ili radnjama bilo oštećeno, a da mu tako nastala šteta nije bila nadoknađena. To se izravno nadovezuje na čl. 497. ZTD-a prema kojem je dužnost članova uprave, odnosno izvršnih direktora, da u prva tri mjeseca poslovne godine izrade izvješće o odnosima društva s povezanim društvima u kojemu, među ostalim, treba navesti sve pravne poslove i radnje koje je ovisno društvo u prethodnoj godini poduzelo $\mathrm{s}$ povezanim društvima ili prema njihovoj uputi, zatim navesti jesu li spomenute radnje dovele do štete te, ako je došlo do štete, je li ona nadoknađena ili je društvo dobilo zahtjev za njezinu naknadu (čl. 497 ZTD).

Slično tome, prema čl. 502 st. 1. ZTD-a članovi nadzornog, odnosno upravnog odbora odgovaraju ako glede pravnoga posla ili štetne radnje povrijede svoju obvezu da provjere izvješće o odnosima s povezanim društvima i da o rezultatu provjere obavijeste skupštinu. To se izravno nadovezuje na čl. 499. ZTD-a prema kojemu nadzorni, odnosno upravni odbor, mora ispitati izvješće o odnosima s povezanim

89 Braut Filipović, M., op. cit. u bilj. 2, str. 822.

90 V. Barbić, J., Društvo s ograničenom odgovornošću, op. cit. u bilj. 5, str. 283 i dalje.

91 Habersack, M., op. cit. u bilj. 6, § 317, para. 27.

92 Dika, M., Stranke, njihovi zastupnici i treći u parničnom postupku, Zagreb, Narodne novine, 2008, str. 75 i dalje.

93 Barbić, J., Društvo s ograničenom odgovornošću, op. cit. u bilj. 5, str. 283 i dalje.

94 VTS Pž 894/07-3 od 10.10.2007.; VTS Pž-3063/05 od 5.6.2008.; VTS Pž-2676/08 od 2.11.2009. 
društvima koje je izradila uprava, odnosno izvršni direktori, i o tome izvijestiti skupštinu.

Te bi odredbe mogle navesti na pogrešan zaključak da je riječ o uređenju kojim se iscrpljuje odgovornost članova organa ovisnoga društva u faktičnom koncernu, odnosno da bi članovi organa bili odgovorni samo ako povrijede svoje dužnosti u vezi s izvješćem o odnosima ovisnoga društva s povezanim društvima. ${ }^{95} \mathrm{Iz}$ općih pravila prava društava i odredbe o granicama utjecaja u faktičnom koncernu (čl. 496 ZTD), međutim, proizlazi da vladajuće društvo nije ovlašteno preuzeti vođenje poslova ovisnoga društva. U kontekstu organa, to znači da organi ovisnoga društva nastavljaju obavljati svoje zakonom dodijeljene zadaće. Dapače, kada se u čl. 496 st. 1. ZTD-a predviđa da vladajuće društvo ne smije koristiti svoj utjecaj da ovisno društvo navede na poduzimanje štetnih radnji, zakon ujedno upućuje organe ovisnoga društva, prvenstveno upravu, da odbiju slijediti takve upute. Provođenjem štetnih uputa članovi uprave ovisnoga društva povrijedili bi svoju dužnost voditi poslove ovisnoga društva pozornošću urednog i savjesnog gospodarstvenika i mogli bi biti odgovorni za štetu prema općim pravilima (čl. 252 ZTD). ${ }^{96}$ Iznimka bi postojala jedino u slučaju kada bi vladajuće društvo nadoknadilo štetu ovisnome društvu ili mu dalo odgovarajući zahtjev do kraja poslovne godine. ${ }^{97}$

S obzirom na to da uprava ovisnoga društva zadržava isključivo pravo voditi poslove ovisnoga društva, vladajuće društvo ne može prisiliti upravu ovisnoga društva niti na provođenje uputa koje su objektivno povoljne po ovisno društvo. ${ }^{98}$ Ako odbije provesti povoljnu uputu, uprava ovisnoga društva maksimalno bi mogla biti odgovorna prema ovisnome društvu zbog povrede pravila o dužnoj pozornosti pri vođenju poslova. ${ }^{99}$

Dakle, nakon što dobije uputu od vladajućeg društva koju želi provesti, uprava ovisnoga društva prvo mora ispitati je li ona štetna za ovisno društvo. To će učiniti primjenjujući kriterije koji su već objašnjeni u podnaslovu o odnosima vladajućeg i ovisnoga društva. ${ }^{100}$ Ako je uputa štetna, uprava ju može odbiti slijediti. Ako bi ju ipak iz bilo kojeg razloga željela provesti, prvo bi morala provjeriti je li uputa barem u interesu vladajućeg društva i s njime povezanih društava, ${ }^{101}$ može li se šteta do koje će uputa dovesti uopće nadoknaditi te je li vladajuće društvo spremno nadoknaditi tu štetu. ${ }^{102}$ Ako vladajuće društvo izjavi da je spremno, uprava mora preispitati je li izgledno da će vladajuće društvo imati dovoljno imovine da udovolji takvom zahtjevu. ${ }^{103}$ Tek ako je na sva pitanja odgovor potvrdan uprava može slijediti uputu

95 Altmeppen, H., op. cit. u bilj. 6, § 318, para. 3.; Habersack, M., op. cit. u bilj. 6, § 318, para. 2; Koch, J., op. cit. u bilj. 6, § 318, para. 1.

96 Koch, J., op. cit. u bilj. 6, § 311, para. 48.; Habersack, M., op. cit. u bilj. 6, § 318, para. 78.

97 Altmeppen, H., op. cit. u bilj. 6, § 311, para. 457, 458 i dalje; Koch, J., op. cit. u bilj. 6, § 311, para. 48.

98 Habersack, M., op. cit. u bilj. 6, § 318, para. 78.

99 Habersack, M., op. cit. u bilj. 6, § 318, para. 78.

100 Podnaslov 3.

101 Usp. s čl. 493 st. 1 ZTD.

102 Barbić, J., Vođenje poslova op. cit. u bilj. 2, str. 1581-1582; Altmeppen, H., op. cit. u bilj. 6, § 311, para. 464, 465; Habersack, M., op. cit. u bilj. 6, § 318, para. 78.

103 Barbić, J., Vođenje poslova op. cit. u bilj. 2, str. 1581-1582; Habersack, M., op. cit. u bilj. 6, § 
bez da se izloži odgovornosti za štetu.

Odgovore na navedena pitanja uprava ovisnoga društva mora dobiti ex ante, prije nego što poduzme radnju štetnu po ovisno društvo. ${ }^{104}$ Koncernski privilegij vladajućeg društva davati štetne upute ovisnome društvu ako se obveže na nadoknadu štete do kraja poslovne godine ne znači da uprava ovisnoga društva može poduzeti štetnu radnju na temelju puke nade da će vladajuće društvo nadoknaditi štetu prije isteka poslovne godine. Uprava prethodno mora provjeriti da je vladajuće društvo ne samo spremno, nego i u mogućnosti naknaditi štetu. Ako vladajuće društvo usprkos tome ne bi nadoknadilo štetu do kraja poslovne godine, ovisno društvo je dovoljno zaštićenom zahtjevom na naknadu štete prema vladajućem društvu i njegovim zakonskim zastupnicima (čl. 501 ZTD-a).

Spremnost i mogućnost vladajućeg društva da nadoknadi štetu u trenutku poduzimanja štetne radnje se, zbog toga, bitno ne razlikuju od zahtjeva za nadoknadom štete koji vladajuće društvo može dati ovisnome društvu sve do kraja poslovne godine (čl. 496 st. 2 ZTD). Razlika je prvenstveno u tome šte se u trenutku poduzimanja štetne radnje konkretan sadržaj zahtjeva za naknadu štete još ne mora točno odrediti. ${ }^{105}$ Drugim riječima, tzv. koncernski privilegij vladajućeg društva uvelike se svodi na privilegij izbora konkretnog načina nadoknade štete do kraja poslovne godine. ${ }^{106}$

Nadalje, čl. 502 st. 4 ZTD-a upućuje na odgovarajuću primjenu čl. 494 st. 3-5. ZTD-a koji uređuju odgovornost zakonskih zastupnika vladajućeg društva u ugovornom koncernu. Kao što je već objašnjeno kod odgovornosti zakonskih zastupnika vladajućeg društva, najvažnija posljedica je ovlaštenje pojedinog člana društva da putem actio pro socio traži naknadu štete u korist društva (čl. 494 st. 4. ZTD-a).

Za funkcioniranje učinkovitog sustava zaštite manjinskih članova i vjerovnika ovisnoga društva u faktičnom koncernu, uloga uprave ovisnoga društva (odnosno njegovih zakonskih zastupnika) je od odlučujuće važnosti. Odredbe o granicama utjecaja vladajućeg društva su, naime, beskorisne ako ne postoji netko tko će prepoznati takve granice, a potom se suprotstaviti utjecaju koji ih prelazi. Upravna ovisnoga društva pri tome odgovara prema općim pravilima odgovornosti iz čl. 252 ZTD.

\section{ZAKLJUČAK}

Da bi pružio odgovor na pitanje o odgovornosti članova organa društava u faktičnom koncernu, ovaj je rad prvo morao razmotriti što je to faktični koncern te kako koncernska pravila uređuju odnos vladajućeg i ovisnog društva.

318, para. 78.

104 Altmeppen, H., Zur Vermögensbindung in der faktisch abhängigen AG, ZIP 1996, str. 696; Habersack, M., op. cit. u bilj. 6, § 318, para. 78.

105 Habersack, M., op. cit. u bilj. 6, § 318, para. 78.

106 Neki autori, dapače, smatraju da i taj privilegij postoji samo ako se nadoknada ne može odrediti prije kraja poslovne godine, odnosno da bi vladajuće i ovisno društvo morali odrediti nadoknadu ovisnome društvu čim je to prije moguće (Altmeppen, H., op. cit. u bilj. 6, § 311, para. 369, 468, 469). 
Utvrđeno je da je faktični koncern ključan kako za opći pojam koncerna tako i za čitavo pravo povezanih društava. Konstitutivni element svakoga koncerna jedinstveno vođenje više društava - je, naime, faktični, gospodarski pojam koji se razlikuje od pravnog pojma vođenja poslova kao inherentno vezanog za pojedino društvo. S druge strane, prvenstvena funkcija većine oblika povezanih društava je stvoriti oborivu presumpciju postojanja faktičnog koncerna. Pri tome treba imati na umu da je za većinu učinaka faktičnog koncerna dovoljan odnos vladajućeg i ovisnog društva, odnosno da ih ne bi isključilo eventualno dokazivanje da vladajuće i ovisno društvo nisu objedinjeni jedinstvenim vođenjem. Zbog toga se vladajuće i ovisno društvo pojavljuju kao najvažniji oblik koncernskog prava u širem smislu.

Za odnos vladajućeg i ovisnog društva dovoljna je mogućnost da jedno društvo vrši prevladavajući utjecaj na drugo društvo. Ta mogućnost mora proizlaziti iz organizacijskih pravila prava društava. Ne traži se, međutim, da organizacijska pravila prava društava dozvoljavaju takvo vršenje utjecaja. Dapače, pravila o nehijerarhijskom dualističkom ustroju organa dioničkog društva izričito zabranjuju vladajućem društvu da preuzme vođenje poslova društva. To najbolje ilustrira kako je zakonodavac bio prisiljen uvažiti stvarni, faktični odnos moći u društvima, odnosno priznati da čak ni članovi uprave ne mogu biti potpuno neovisni o članu društva kojemu mogu zahvaliti svoje imenovanje. Ukratko rečeno, vladajuće društvo redovito može više nego što bi smjelo.

Zbog toga ne začuđuje da je prvenstvena svrha učinaka faktičnog koncerna $u$ odnosima vladajućeg i ovisnoga društva ograničiti utjecaj vladajućeg društva na štetu manjinskih članova i vjerovnika ovisnoga društva. Osnovno je pravilo da vladajuće društvo ne smije davati ovisnome društvu upute da poduzme radnju koja je za njega štetna. Štetnost radnje procjenjuje se usporedbom s ponašanjem fiktivnog, neovisnog, uredno vođenog društva, koje je, uz iznimku ovisnosti, istovjetno ovisnome društvu.

Vladajuće društvo iznimno smije davati ovisnome društvu upute da poduzme štetnu radnju ako nadoknadi ovisnome društvu štetu do kraja poslovne godine ili ako mu dade zahtjev za nadoknadu takve štete. Riječ je o, tzv. koncernskom privilegiju koji omogućuje vladajućem društvu da ovisnome društvu nadoknadi štetu uz vremensku odgodu. Takvo se pravilo može opravdati samo ako ne dovede manjinske članove i vjerovnike ovisnoga društva u lošiji položaj od onoga u kojemu bi se nalazili da ne postoji faktični koncern. Zbog toga je vladajuće društvo ovlašteno uputiti ovisno društvo na poduzimanje štetne radnje samo ako je izgledno da će moći nadoknaditi gubitak do kraja poslovne godine. Ako vladajuće društvo nije spremno nadoknaditi gubitak, ili je upitna njegova solventnost, ovisno društvo bi moralo odbiti slijediti danu uputu.

Protuteža koncernskom privilegiju vladajućeg društva objektivna je odgovornost za štetu vladajućeg društva koje je uputilo ovisno društvo na poduzimanje štetne radnje bez da je nadoknadilo štetu do kraja poslovne godine. Ta odgovornost postoji usprkos okolnosti da prema općim pravilima prava društava vladajuće društvo nema dužnost voditi poslove ovisnoga društva. Usporedno s odgovornošću vladajućeg društva, zakon predviđa i odgovornost njegovih zakonskih zastupnika. To pravilo primorava zakonske zastupnike vladajućeg društva da primijene oprez pri davanju 
uputa ovisnome društvu. Ipak nema potrebe ići toliko daleko i njihovu odgovornost shvaćati kao objektivnu. Umjesto toga, njihovu odgovornost treba, što je moguće više, prilagoditi općim pravilima odgovornosti za vođenje poslova vlastitoga društva.

Naposljetku, posebna koncernska pravila o odgovornosti članova organa ovisnoga društva ne smiju sakriti da članovi organa ovisnoga društva odgovaraju, prema općim pravilima, za povredu pozornosti urednog i savjesnog gospodarstvenika pri vođenju poslova ovisnoga društva. Takva je odgovornost najvažnija za učinkovito funkcioniranje pravila o granicama utjecaja vladajućeg društva. Uprava ovisnoga društva je, naime, ta koja prije poduzimanja radnje mora procijeniti je li uputa vladajućeg društva štetna, a ako utvrdi da je to slučaj, je li vladajuće društvo spremno i u mogućnosti nadoknaditi štetu do kraja poslovne godine. Ako je uputa štetna, a nije izgledno da će vladajuće društvo nadoknaditi štetu, uprava ovisnoga društva mora odbiti uputu inače će sama biti odgovorna za nastalu štetu. Ako pak uputa nije štetna ili je izgledno da će šteta biti nadoknađena, uprava ovisnoga društva slobodno procjenjuje hoće li ju slijediti vodeći isključivo računa o interesima ovisnoga društva.

Može se, prema tome, zaključiti da specifična pravila faktičnog koncerna znatno ne mijenjaju opća pravila korporativnog upravljanja. Ipak, s obzirom na iznimnu važnost tih pravila i brojnost faktičnih koncerna, već i mala odstupanja, konkretno koncernski privilegij vladajućeg društva te odgovornost za štetu vladajućeg društva i njegovih zakonskih zastupnika, mogu imati značajne posljedice za pravo društava kapitala. U tom kontekstu, može se izraziti žaljenje da sudska praksa relativno rijetko prepoznaje faktične koncerne vladajućeg i ovisnoga društva i nadu da će se to promijeniti u budućnosti.

\section{LITERATURA}

\section{Knjige i članci:}

1. Altmeppen, Holger, Grundlegend Neues zum „qualifiziert faktischen“ Konzern und zum Gläubigerschutz in der Einmann-GmbH, ZIP 2001, str. 1837-1847.

2. Altmeppen, Holger u: Goette, W.; Habersack, M. (ur.), Münchener Kommentar zum Aktienrecht, Band 5, München, C. H. Beck/Franz Vahlen, 2015., § 311-318 AktG.

3. Altmeppen, Holger, Zur Vermögensbindung in der faktisch abhängigen AG, ZIP 1996, str. 693-698.

4. Bayer, Walter u: Goette, W.; Habersack, M. (ur.), Münchener Kommentar zum Aktienrecht, Band 1, München, C. H. Beck, 2016., § 15-19 AktG.

5. Barbić, Jakša, Koncern i društva koncerna, Pravo u gospodarstvu, vol. 46, 4/2007, str. 57-94.

6. Barbić, Jakša, Pravo društava, Knjiga prva, Opći dio, Zagreb, Organizator, 2008.

7. Barbić, Jakša, Pravo društava, Knjiga druga, Društva kapitala, Svezak I., Dioničko društvo, Zagreb, Organizator, 2013.

8. Barbić, Jakša, Pravo društava, Knjiga druga, Društva kapitala, Svezak II., Društvo s ograničenom odgovornošću, Zagreb, Organizator, 2013.

9. Barbić, Jakša, Vođenje poslova i upravljanje u trgovačkim društvima (povezana društva), Hrvatska gospodarska revija, vol. 45, 11/1996, str. 1574-1582.

10. Braut Filipović, Mihaela, Odgovornost društva majke za obveze društva kćeri, Zbornik Pravnog fakulteta Sveučilišta u Rijeci, vol. 32, 2/2011, str. 795-828. 
11. Ceronja, Petar, O odgovornosti članova nadzornog odbora ovisnog društva za štetu zbog povrede obveze nadzora tražbina iz ugovora o zajmu sklopljenih između ovisnog i vladajućeg društva, Pravo u gospodarstvu, vol. 50, 5/2011, str. 1158-1176.

12. Cindori, Vladimir, Izvješće o ovisnosti trgovačkih društava s aspekta poslovanja društava, Informator, 5436/2006, str. 6-8.

13. Dika, Mihajlo, Stranke, njihovi zastupnici i treći u parničnom postupku, Zagreb, Narodne novine, 2008.

14. Emmerich, Volker u: Emmerich, V.; Habersack, M.; Schürnbrand, J. (ur.), Aktien- und GmbH-Konzernrecht, München, C. H. Beck, 2016., § 15-18 AktG.

15. Gorenc, Vilim (ur.), Komentar Zakona o trgovačkim društvima, Zagreb, RRiF, 2008.

16. Gorenc, Vilim, Povezana društva prema Zakonu o trgovačkim društvima, Računovodstvo, revizija i financije, vol. 4, 10/1994, str. 1786-1797.

17. Grigoleit, Hans Christoph u: Grigoleit, H.-C. (ur.), Aktiengesetz Kommentar, München, C. H. Beck, 2013, § 317, para. 4.

18. Habersack, Mathias u: Emmerich, V.; Habersack, M.; Schürnbrand, J. (ur.), Aktien- und GmbH-Konzernrecht, München, C. H. Beck, 2016, § 311-318 AktG.

19. Jurić, Dionis, Odgovornost vladajućeg društva za obveze ovisnog društva u hrvatskom i usporednom pravu, Zbornik Pravnog fakulteta Sveučilišta u Rijeci, vol. 23, 2/2002, str. 507-540.

20. Jurić, Dionis, Transparentnost statusnih i financijskih odnosa povezanih društava, Zbornik Pravnog fakulteta Sveučilišta u Rijeci, vol. 27, 2/2006, str. 939-984.

21. Koch, Jens u: Hüffer, U.; Koch, J. (ur.), Aktiengesetz, München, C. H. Beck, 2015., § 15-19, § 311-318 AktG.

22. Krieger, Gerd u: Hoffmann-Becking, M. (ur.), Münchener Handbuch des Gesellschaftsrechts, Band 4, München, C. H. Beck, 2015, § 69-70.

23. Ledić, Dragutin, Povezana društva - začetak hrvatskog prava koncerna, Zbornik Pravnog fakulteta Sveučilišta u Rijeci, vol. 16, 1/1995, str. 37-51.

24. Liebscher, Thomas u: Fleischer, H.; Goette, W. (ur.), Münchener Kommentar zum GmbHG, Band 1, München, C. H. Beck, 2018, Anh. § 13.

25. Lieder, Jan, u: Heidinger, A.; Leible, S.; Schmidt, J. (ur.), Kommentar zum GmbHG, Band 1, München, C. H. Beck, 2017, § 13.

26. Moslavac, Bruno, Pitanje odgovornosti u slučaju ovisnosti društva kada nema ugovora o vođenju poslova društva, Informator, vol. 56, 5695-5696/2008, str. 5-7.

27. Müller, Hans-Friedrich u: Spindler, G.; Stilz, E. (ur.), Kommentar zum Aktienrecht, Band 2, München, C. H. Beck, 2015, § 311-318 AktG.

28. Schall, Alexander u: Spindler, G.; Stilz, E. (ur.), Kommentar zum Aktienrecht, Band 1, München, C. H. Beck, 2015, § 15-19 AktG.

29. Spindler, Gerald u: Goette, W.; Habersack, M. (ur.), Münchener Kommentar zum Aktienrecht, Band 2, München, C. H. Beck/Franz Vahlen, 2014, § 76.

30. Stephan, Klaus-Dieter; Tieves, Johannes u: Fleischer, H.; Goette, W. (ur.), Münchener Kommentar zum GmbHG, Band 2, München, C. H. Beck, 2016, § 37.

31. Vidović, Ante, Koncern - aktualna pitanja povezivanja društava, Računovodstvo, revizija i financije, vol.18, 3/2008, str. 194-195.

\section{Pravni akti:}

1. Njemački Zakon o dioničkim društvima, Aktiengesetz.

2. Zakon o obveznim odnosima, NN, br. 35/2005, 41/2008, 125/2011, 78/2015, 29/2018.

3. Zakon o računovodstvu, NN, br. 78/15, 134/15, 120/16.

4. Zakon o trgovačkim društvima, NN, br. 111/93, 34/99, 121/99, 52/00, 118/03, 107/07, 146/08, 137/09, 125/11, 111/12, 68/13 i 110/15.

5. Ustav Republike Hrvatske, NN, br. 56/1990, 135/1997, 113/2000, 28/2001, 76/2010, $5 / 2014$. 
Sudska praksa:

1. VSRH Revt 159/11-2 od 24.1.2012.

2. VSRH Revt 60/04-2 od 6.10.2004.

3. VSRH Revr 344/08-2 od 17.6.2009.

4. VTS Pž-1934/06-3 od 22.4.2009.

5. VTS Pž-1760/02 od 15.4.2003.

6. VTS Pž 2859/04-3 od 6.11.2007.

7. VTS Pž 7222/04-3 od 11.10.2005.

8. VTS Pž 6097/05-3 od 29.5.2007.

9. VTS Pž 3289/2017-2 od 29.5.2017.

10. VTS Pž 894/07-3 od 10.10.2007.

11. VTS Pž-3063/05 od 5.6.2008.

12. VTS Pž-2676/08 od 2.11.2009. 


\author{
Antun Bilić* \\ Siniša Petrović**
}

Summary

\title{
THE LIABILITY OF BOARD MEMBERS IN A FACTUAL GROUP OF COMPANIES
}

The paper analyses key issues of liability of board members in companies which form a so-called factual group of companies. The liability of board members is a natural consequence of their powers. In order to determine the scope of boards' powers, the paper assesses, first, the notion of a factual group of companies and, second, the relationship between a parent and subsidiary company. It can be concluded that, although it is not allowed, parent company is often in a position to force subsidiary company to undertake certain actions. Therefore, the primary goal of the provisions which limit the influence of a parent company is to protect minority shareholders and creditors of the subsidiary company. Parent company is allowed to give harmful instruction to its subsidiary only exceptionally, when it compensates the harm to the subsidiary before the end of the business year. Such a privilege of the parent company is balanced by the rules on the objective liability of the parent company and the presumed liability of its statutory representatives. The management board of the subsidiary company has a key role in its effective protection because it is has to evaluate, with a care of a diligent businessperson, if the instructions of the parent company are harmful to the subsidiary and if they are, is the parent company ready and able to compensate the harm.

Keywords: factual group of companies, parent and subsidiary company, limits on the influence of the parent company, liability of board members, management board.

* Antun Bilić, Ph. D., postdoctoral student, Faculty of Law, University of Zagreb; antun.bilic@ pravo.hr.

** Siniša Petrović, Ph. D., Full Professor, Faculty of Law, University of Zagreb; sinisa.petrovic@ pravo.hr. 
Zussamenfassung

\section{HAFTUNG DER MITGLIEDER DER GESELLSCHAFTSORGANE IN EINEM FAKTISCHEN KONZERN}

Die Arbeit bespricht die wichtigsten Fragen der Haftung der Mitglieder der Gesellschaftsorgane in einem faktischen Konzern. Die Haftung der Mitglieder der Gesellschaftsorgane in einem faktischen Konzern hängt von dem Ausmaß ihrer Befugnisse ab. Um diese Befugnisse festzustellen, setzt man sich in der Arbeit zuerst mit dem Begriff des faktischen Konzerns im Kontext des Rechts von verbundenen Unternehmen auseinander, wonach man auch die Einwirkungen des Konzernrechts auf die Beziehung zwischen dem herrschenden und abhängigen Unternehmen erörtert. Es wird die Schlussfolgerung gezogen, dass, obwohl das nicht zulässig ist, das herrschende Unternehmen das abhängige Unternehmen zur Vornahme einer Handlung veranlassen kann. Deshalb ist der Zweck der Regeln über die Grenzen der Einflussnahme des herrschenden Unternehmens, die Minderheitsgesellschafter und Gläubiger des abhängigen Unternehmens durch das Verbot der zum Schaden des abhängigen Unternehmens gegebenen Weisungen zu schützen. Das herrschende Unternehmen ist befugt, schädigende Weisungen dem abhängigen Unternehmen nur in Ausnahmefällen zu geben, wenn es ihm später den Nachteil ersetzt oder wenn es sich verpflichtet, diesen Nachteil bis zum Ende des Geschäftsjahres zu ersetzen. Solches Privilegium des herrschenden Unternehmens ist durch die Regeln über objektive Schadenshaftung des herrschenden Unternehmens und durch die Regeln über vermutliche Schadenshaftung gesetzlicher Vertreter des herrschenden Unternehmens ins Gleichgewicht gebracht. Der Vorstand des abhängigen Unternehmens spielt die größte Rolle bei selbigem einwirkungsvollen Schutz. Der Vorstand ist demnach verpflichtet, mit der Sorgfalt eines ordentlichen und gewissenhaften Kaufmanns zu schätzen, ob die Weisungen zum Schaden des abhängigen Unternehmens gegeben wurden und ob das herrschende Unternehmen bereit und fähig ist, deren Nachteil zu ersetzen.

Schlüsselwörter: faktische Konzerne, herrschendes und abhängiges

Unternehmen, Grenzen der Einflussnahme des

herrschenden Unternehmens, Haftung der Mitglieder der

Gesellschaftsorgane, Vorstand. 
Riassunto

\section{RESPONSABILITA' DEI MEMBRI DEGLI ORGANI SOCIETARI IN GRUPPI DI SOCIETA' DI FATTO}

Nel lavoro si disaminano le più rilevanti questioni relative alla responsabilità dei membri degli organi societari che fanno parte di un gruppo di società di fatto. La responsabilità dei membri degli organi societari che fanno parte di un gruppo di società di fatto dipende in maniera significativa dall'ampiezza dei loro poteri. Al fine di accertare l'ampiezza di tali poteri, prima di tutto occorre analizzare la nozione di gruppo di società di fatto nel contesto del diritto delle società collegate; mentre successivamente vanno considerati gli effetti del diritto del gruppo relativamente al rapporto tra società controllante e società controllate. Si giunge alla conclusione che, benché non dovrebbe, la società controllante può imporre alla società controllata di tenere un determinato comportamento. Per questo motivo il fine primo della regola della limitazione dell'ingerenza della società controllante è rappresentato dalla tutela dei membri di minoranza e dei creditori della società controllata mediante il divieto di impartire istruzioni che potrebbero essere dannose per la società controllata. La società controllante è autorizzata ad impartire istruzioni dannose alla società controllata soltanto in via eccezionale quando s'impegni a risarcirla al massimo entro la fine dell'anno finanziario. Tale privilegio della società controllante è contemperato dalle regole di responsabilità oggettiva per danni della società controllante e dalle regole sulla responsabilità per danni dei suoi rappresentanti legali in base alla colpa presunta. Al fine di una tutela efficace della società controllata è di fondamentale importanza il ruolo della sua amministrazione, la quale è tenuta secondo i criteri dettati dal coscienzioso e buon imprenditore alla valutazione dell'eventuale dannosità delle istruzioni per la società controllata e, se lo fossero, a stimare se la società controllante sia pronta ed in grado di provvedere al risarcimento.

Parole chiave: gruppo di società di fatto, società controllante e controllata, limiti dell'ingerenza della società controllante, responsabilità dei membri degli organi, amministrazione. 